\title{
Fundamentals and Stock Returns in Japan
}

\author{
Louis K.C. Chan, Yasushi Hamao, \\ and Josef Lakonishok
}

Working Paper No. 45

Louis Chan and Josef Lakonishok are from the College of Commerce and Business Administration, University of Illinois at Urbana-Champaign. Yasushi Hamao is from the Graduate School of International Relations and Pacific Studies, University of California, San Diego. The article has been presented at Purdue University, the University of California at Irvine, the Stockholm School of Economics, the London Business School, INSEAD, the CRSP Seminar on the Analysis of Security Prices at Chicago, and the Berkeley Program in Finance in Tokyo. The authors appreciate helpful comments by Bill Bryan, Nai-Fu Chen, Don Keim, Claudio Loderer, Jay Ritter, Dennis Sheehan, Neal Staughton, and Yuk Tse, and are grateful to Takeo Hoshi and Bing Yeh for their help with data collection and to Brian Bielinski for research assistance.

Working Paper Series

Center on Japanese Economy and Business

Graduate School of Business

Columbia University

May 1990 


\begin{abstract}
This paper relates cross-sectional differences in returns on Japanese stocks to the underlying behavior of four fundamental variables: earnings yield, size, book to market ratio, and cash flow yield. Alternative statistical specifications and various estimation methods are applied to a comprehensive, high-quality data set that extends from 1971 to 1988 . The sample includes both manufacturing and non-manufacturing firms, companies from both sections of the Tokyo Stock Exchange, and aiso delisted securities. Our findings reveal a significant relationship between fundamental variables and expected returns in the Japanese market. Of the four fundamental variables considered, the book to market ratio and cash flow yield have the most significant positive impact on expected returns.
\end{abstract}


The Japanese and the U.S. equity markets are, by far, the two largest in the world. As of March 1990, the two markets together accounted for 67 percent of the world's stock capitalization. In recent years, money managers in the U.S., as well as in other countries, have substantially increased their exposure to the Japanese market. In spite of the Japanese market's rapid growth and increasing significance in the international financial arena, however, it is only recently that researchers have turned their attention to the Tokyo market.

In contrast to the voluminous research in the U.S. relating stock returns to such fundamental variables as firm size, earnings yield, cash flow yield and book to market value, there has been only very limited research relating to the Japanese market. Moreover, the available Japanese evidence suffers from methodological problems and a limited data base. For instance, previous studies focused on a subset of stocks traded in the first section (the largest companies) for a relatively short time period and used only a limited set of fundamental variables. To the best of our knowledge, information on delisted companies was not available in previous studies; hence, the studies also suffer from a survivorship bias.

The purpose of our study is to fill this void by exploring the relationship between equity returns and fundamental variables in Japan. The results provide evidence on which fundamental variables (if any) are at work in the Japanese market. In contrast to earlier papers, we use a comprehensive, high quality data set. Our data extends over a relatively long period of time (1971 to 1988) and contains most of the companies in both the first and second sections of the Tokyo Stock Exchange, including delisted companies. The set of fundamental variables employed is also more exhaustive than in previous papers; it includes earnings yield, cash flow yield, size (market capitalization of equity) and book to market ratio (of equity).

Studying a market as important as the Japanese stock market is of interest in its own right. In addition, our results, when placed alongside the evidence accumulated from studies of American data, may also be useful in evaluating empirical models of the determinants of stock returns. Wherever possible, therefore, we attempt to draw parallels between our findings and those from similar studies using American data. In particular, the unprecedented appreciation of the Japanese stock market in recent years has raised doubts as to whether fundamental valuation techniques developed in the U.S. apply to Japan. In a recent Wall Street Journal article, M. Brauchli describes the Japanese market in the following terms: "Imagine a stock market where investors ignore basic fundamentals such as earnings and corporate growth prospects. A 
market driven by floods of money. A market trading at mind-boggling price levels." (April 25, 1990) A number of recent papers, surveyed in Frankel (1989), evaluate alternative explanations of the level of Japanese equity prices. French and Poterba (1990), for example, conclude that differences in accounting systems, discount rates and expected growth do not seem to explain the high level of Japanese stock prices. On the one hand, finding that the same factors are at work in the two countries would strengthen our confidence in the evidence accumulated for the U.S. An often-encountered criticism of studies using U.S. data is that they are subject to data-snooping biases (e.g. Lakonishok and Smidt (1988) and Lo and MacKinlay (1989)). Since stock prices have been studied so extensively, data-snooping biases are particularly likely to be an issue. Fresh data, especially from one of the two largest stock markets in the world, is the best remedy. On the other hand, finding that different factors are at work in the two countries would suggest further research exploring institutional or behavioral differences between the two countries. For example, Japanese regulations do not allow companies to use different reporting methods for tax purposes and for public financial statements. As a result, companies predominantly use accelerated depreciation methods for financial reporting. Firms with large capital investments thus tend to have substantially understated earnings. Hence, we examine cash flow (earnings plus depreciation) yield in addition to earnings yield as an additional fundamental variable.

In the U.S., the empirical relation between stock returns and fundamental variables has been extensively studied. Furthermore, valuation models using fundamental variables have been widely used by practitioners for at least 50 years. The results of previous studies are in general considered to be anomalous; a positive relationship was found between equity returns and earnings yield, cash flow yield and book to market ratio, and a negative relationship was found between equity returns and size. Especially voluminous are the studies that document the size and the earnings yield effects and studies that try to disentangle the two effects. See, for example, Basu (1977, 1983), Banz (1981), Reinganum (1981), Cook and Rozeff (1984), Lakonishok and Shapiro (1986), Banz and Breen (1986), Jaffe, Keim and Westerfield (1989), and Ritter and Chopra (1989). The shortcomings of accounting earnings motivated a number of recent papers to explore the relationship between cash flow yields and stock returns (Bernard and Stober (1989) apd Wilson (1986)). Rosenberg, Reid, and Lanstein (1984) study the relationship between stock returns and the book to market ratio. 
Despite extensive research, a consensus has not yet emerged on three issues. Are some or all of these fundamental variables proxying for omitted risk factors? Does one fundamental variable (e.g. earnings yield) subsume another (e.g. size)? Are the results robust to time period and sample composition? Evidence from the Japanese market will shed some light on these issues.

Academic interest in the Japanese market is a relatively recent phenomenon. Hamao (1989) and Hamao and Ibbotson (1989) characterize the Japanese capital markets by presenting summary statistics. Tests of the Capital Asset Pricing Model for the Tokyo Stock Exchange by both Maru and Yonezawa (1984) and Hawawini (1988) report that the model fits rather poorly. The multi-factor model or the Arbitrage Pricing Theory is examined by Elton and Gruber (1988), Hamao (1988), and Brown and Otsuki (1990); they all obtain significant supporting evidence for the model. Gultekin, Gultekin, and Penati (1989) apply the APT framework to document the increasing degree of international capital market integration between the U.S. and Japan. Campbell and Hamao (1989) examine the integration in terms of the long-run comovements of expected returns, while Hamao, Masulis and $\mathrm{Ng}$ (1990) document short-run relationships between returns and volatility across international markets.

In addition, the information content of the release of accounting reports is examined by Sakakibara, Yamaji, Sakurai, Shiroshita, and Fukuda (1988) and Darrough and Harris (1989). Elton and Gruber (1989) analyze the relationship between expectational data and actual stock performance. The difference between U.S. and Japanese P/E multiples is examined by Bildersee, Chen and Lee (1990), and French and Poterba (1990).

Finally, there are several studies that deal with anomalous price behavior on the Tokyo Stock Exchange. Jaffe and Westerfield (1985) present day-of-the-week and turn-of-the-year patterns in daily index returns. Daily patterns are also investigated using intraday index returns by Kato, Ziemba and Schwartz (1990). Nakamura and Terada (1984) and Kato and Schallheim (1985) document size and seasonal anomalies, while Nakamura and Terada (1984) and Aggarwal, Hiraki and Rao (1986) document P/E and size effects.

Our findings reveal a significant relationship between fundamental variables and expected returns in the Japanese market. Of the four variables considered, the book to market ratio and cash flow yield have a reliably positive impact on expected returns. The performance of the size variable, although in general 
consistent with previous findings, turns out to be highly dependent on the specific model and time period. While previous studies document a strong positive earnings yield effect, we find no such evidence after controlling for the other variables. These conclusions are based on a variety of alternative statistical specifications. In explaining expected stock returns, extra care should in general be taken to verify the robustness of results before drawing any firm conclusions.

The remainder of the paper is structured as follows. In Section I, we describe our data. In Section II, we present the methodology for testing the relationship between stock returns and fundamental variables. Results from univariate analyses are in Section III. In Section IV, we present the results from regression models. Section $V$ examines the robustness of the results. Potential profits from trading strategies based on the fundamental variables are documented in Section VI. The paper concludes in Section VII with a summary of the findings.

\section{Data Description}

We use monthly data on stocks listed on the Tokyo Stock Exchange (TSE) from January 1971 to December 1988. The Tokyo Stock Exchange, which accounts for more than 85 percent of total market capitalization of Japanese equity, consists of two sections. The distinction between the two sections is similar to that between the NYSE and AMEX. Typically, smaller firms are listed on the second section, and may move to the first section when they satisfy the standards set by the exchange. ${ }^{\dagger}$ The number of companies in the sample changes over time, reflecting new listings and delistings.

Monthly returns (including dividends) and market capitalization are from the database compiled by Hamao in collaboration with Daiwa Securities Co., Ltd., Tokyo. This database is comparable to the CRSP (Center for Research in Security Prices at the University of Chicago) monthly database and is described in Hamao and Ibbotson (1989). Two market indexes, an equally weighted and a value weighted portfolio of all the stocks of the first and second sections of the TSE, are also derived from these data. ${ }^{2}$ Since there is no Japanese equivalent to U.S. Treasury bills, we use a combined series of the call money rate (January 1971 November 1977 ) and the 30-day Gensaki (repo) rate (December 1977 - December 1988) as a risk-free

interest rate. This interest rate series is taken from Hamao and Ibbotson (1989). The data on the remaining 
three fundamental variables -- earnings yield, cash flow yield (earnings plus depreciation) and book to market ratio -- are based on Nihon Keizai Shimbun Sha (1971 through 1988) as recorded by Daiwa Securities. ${ }^{3}$

Aside from their limited database, previous studies of the Japanese market are subject to the following two problems. First, it is typical for commercial databases to disregard delisted companies. This problem is not unique to Japan. Therefore, studies using such databases suffer from survivorship bias which, as Banz and Breen (1986) find, might lead to distorted results. Secondly, it has been customary in Japan to limit the sample to manufacturing companies since accounting data on non-manufacturing (especially financial) companies are difficult to obtain. However, the non-manufacturing sector is very large in Japan; for example, in December 1988, the financial sector alone constituted 11 percent of the number of listed firms and 30 percent of total market capitalization.

In contrast, our data set includes delisted stocks and non-manufacturing companies. There are 123 companies that were delisted from either section of the Tokyo Stock Exchange from 1971 to 1988 . While this includes firms that merged for strategic reasons, the majority experienced financial difficulties. In order to warn investors, stocks that fail to satisfy the listing requirements are moved to the "warning post" by the Tokyo Stock Exchange for three months prior to delisting. Our data on these companies are up to the last month of being on the warning post. The accounting data on financial institutions are also obtained from Nihon Keizai Shimbun Sha (1971 through 1988). As of December 1988 the entire sample includes 1570 companies, 1130 of which are in the first section.

The majority of Japanese firms have March as the end of their fiscal year. As of the end of 1988,68 percent of the firms were on a March cycle. Some firms publish semi-annual statements; we do not use these because of their tentative nature. The data available to us are from the parent-only financial statements. Consolidated financial statements, which became mandatory only after 1978, are usually released after a substantial delay -- one to two months after the release of the parent-only statements. Also, Darrough and Harris (1989) found, in a forecasting context, that the parent-only accounting information is most relevant and Ishizuka (1987) found that the parent-only statements have more influence on stock prices than consolidated statements. 
While a firm's stock price changes every month, its accounting numbers are updated only once a year, in the month of announcement of the annual statements. All the fundamental variables change every month because of the fluctuation in stock prices.

To summarize, our database is the most complete relative to prior studies: (1) it contains all available firms from both the first and second sections, (2) the sample period is from 1971 to 1988, (3) it includes delisted firms, and (4) it comprises the most comprehensive list of fundamental variables.

\section{Methodology}

The analysis of the relationship between stock returns and fundamental variables is conducted at the portfolio level. As stated, most companies in Japan have a fiscal year that ends on March 31 , and as in the U.S., practically all companies publish their financial statements within three months after the end of the fiscal year. Accordingly, the portfolios we use are formed on the basis of the fundamental variables known to investors as of the end of June for firms with March 31 and non-March 31 fiscal year ends. This ensures that our tests are predictive in nature.

To form portfolios, a three-way grouping procedure is employed. Forming portfolios on the basis of all the four fundamental variables would yield too few stocks per portfolio. In the first step, firms are ranked by earnings yield as of the end of June in each year and placed into one of five groups. Group 0 contains stocks with negative earnings and groups one to four each contain an equal number of firms with positive earnings. Group 1 comprises firms with the lowest positive earnings yields while group 4 comprises those firms with the highest positive earnings yields. Each earnings yield group is then divided into four subgroups on the basis of size. Subgroup 1 contains the stocks with the lowest capitalization while the largest stocks are placed in subgroup 4. Each of these groups is in turn divided into five groups based on book to market ratio. Stocks with negative book value are placed in subgroup 0; the remaining firms are sorted into four groups in increasing order of book to market ratio. Each stock receives the same weight within its portfolio. The result is a three-way grouping with a total number of 100 portfolios $(5 \times 4 \times 5)$. In line with previous studies, we focus in the regression analysis on firms with positive earnings and book values at the grouping stage, thus a total of 64 portfolios $(4 \times 4 \times 4)$. This portfolio formation procedure is updated in June of each subsequent year. 
We employ the Seemingly Unrelated Regression (SUR) model to adjust simultaneously for portfolio risk and test for the significance of the fundamental variables. Our basic model is

$$
\begin{aligned}
& R_{p_{t}}-R_{t t}=\alpha_{0}+\beta_{p_{1}}\left(R W_{t}-R_{f t}\right)+\beta_{p_{2}}\left(R E_{t}-R_{t t}\right)+\alpha_{1}(E / P)_{p t}+\alpha_{2}(L S)_{p t} \\
& +\alpha_{3}(B / M)_{p_{t}}+\alpha_{4}(C / P)_{p t}+e_{p t} \\
& P=1, \ldots 64 \quad t=1, \ldots 210 .
\end{aligned}
$$

The dependent variable is the return on portfolio $P$ in month $t, R_{P t}$, less the risk-free rate in month $t, R_{t t}$. $R W_{t}$ is the return on a value weighted index in month $t$, while $R E_{t}$ is the return on an equally weighted index in month t. The indexes contain all stocks from both the first and the second sections. The fundamental variables analyzed include $(E / P)_{P_{t}}$, the average earnings yield for portfolio $P$ in month $t$; $(L S)_{P t}$, the average of the natural logarithm of market capitalization for firms in portfolio $\mathrm{F}$ in month $\mathrm{t}$; $(\mathrm{B} / \mathrm{M})_{\mathrm{pt}}$, the average book to market value for portfolio $\mathrm{P}$ in month $\mathrm{t}$ and $(\mathrm{C} / \mathrm{P})_{\mathrm{Pt}}$, the average cash flow yield for portfolio $\mathrm{P}$ in month $t^{4}$ All the fundamental variables are known at the beginning of month $t$.

Preliminary analysis showed that returns for typical companies track an equally weighted index substantially better than a value weighted index. For example, in regressions of portfolio returns on index returns, the $\mathrm{R}^{2}$ averaged across the 64 portfolios is 74 percent for an equally weighted index and 27 percent for a value weighted index. For larger companies, however, the $\mathrm{R}^{2}$ is substantially higher if a value weighted index is used. Therefore, in the spirit of Huberman and Kandel (1985), we use two factors, the equally and value weighted indexes, to account for market-wide risk.

Equation (1) provides a compact summary of the relation between stock returns and fundamental variables. We also examine models based on subsets of the fundamental variables, and examine the sensitivity of the results to the procedures used for portfolio formation (order of grouping) and sample selection (by including or excluding second section stocks).

The SUR methodology used to estimate equation (1) is popular in the finance literature, with Jaffe, Keim and Westerfield (1989) being a recent example. This methodology has two main agvantages: (1) betas are estimated simultaneously with the impact of the fundamental variables and (2) the procedure adjusts for the cross-sectional correlation in the residual returns across portfolios. ${ }^{5}$ However, there is a strong 
possibility for bias in the way that the SUR methodology has been applied in prior research. The SUR approach can be viewed as conducting a time-series regression for each of the 64 portfolios, requiring that the coefficients of the fundamental variables be the same across all portfolios, and finally adjusting the estimates for the cross-correlation in the residual returns. On the other hand, the underlying economic hypothesis is that, at any point in time, cross-sectional differences in returns across stocks are determined by cross-sectional differences in their fundamental variables. The cross-sectional distribution of fundamental variables may vary over time, however. For example, suppose that size is an important fundamental variable. Then a company whose absolute size is the same in 1971 and 1988 would not have the same market-adjusted return, if its size relative to its peer firms has changed over time. Indeed, the level of fundamental variables in Japan has changed substantially over time, due to the unprecedented appreciation in the value of Japanese stocks. For example, large companies in 1971 (the earliest year in our sample) would not be considered large in 1988; a P/E ratio of 15 would be considered very high in some years and low in others. An adjustment for the level of the fundamental variables in any particular year is therefore essential. We perform such an adjustment by dividing each fundamental variable every month by its corresponding crosssectional average from the previous June, thus preserving cross-sectional differences when pooling data across time.

As an alternative to the SUR methodology, we also apply the Fama-MacBeth (1973) methodology. The two methodologies are different and the sensitivity of the results to the various procedures is of interest. The SUR methodology assumes that the betas for the portfolios are constant over time, whereas the FamaMacBeth procedure updates betas periodically. The Fama-Macbeth methodology, unlike the SUR model, also allows the coefficients of the explanatory variables to vary across months. These coefficients are then averaged across time. Such aggregation, however, assumes that the coefficients are drawn from an underlying stationary distribution. Since the level of an independent variable affects the magnitude of its coefficient, dramatic growth over time in the levels of the explanatory variables may invalidate the assumption of a stationary distribution. In order to alleviate this potential non-stationarity, we again follow the procedure of dividing the fundamental variables in each month by its corresponding cross-sectional average from the previous June. In addition, estimating the monthly cross-sectional regressions by ordinary least squares is likely to be inefficient, since the residuals across portfolio groups are in general correlated. In 
order to obtain a more powerful test, we also carry out the Fama-MacBeth methodology using generalized least squares for each monthly cross-section.

In a related context, the findings of Chen and $\operatorname{Kan}(1989)$ further emphasize the importance of verifying the robustness of results to econometric procedures. Chen and Kan found that a variable (the bidask spread) that is an important predictor for portfolio returns using one approach becomes insignificant using another approach.

We also check whether the results are sensitive to the methods used to form portfolios and to sample selection. Our tests are replicated using portfolios formed by different orderings of the four fundamental variables. Previous research on the Japanese market focused on the largest stocks -- those stocks that are traded in the first section. We estimate our models for all the firms in the sample and separately for the first and second section firms. Our time period is relatively long, enabling us also to produce results for two subperiods and to observe possible changes over time.

All our tests hitherto use data on portfolios, where securities are ranked and grouped into portfolios on the basis of various fundamental characteristics. In an important recent paper, Lo and MacKinlay (1989) point out some difficulties with statistical tests based on data grouped by some empirically-motivated fundamental attributes (such as size). In particular, the portfolio grouping approach may bias test statistics and spuriously exaggerate the relationship between portfolio excess returns and the fundamental attributes. The analysis of Lo and MacKinlay (1989), however, also suggests that the bias is less severe if data on individual securities is used, without grouping into portfolios. In order to guard against the possibility that our conclusions are distorted by biased test statistics, we apply the Fama-MacBeth procedure to data on individual securities, instead of portfolios.

Prior research, especially a recent paper by Jaffe, Keim, and Westerfield (1989), indicates that the relationship between equity returns and fundamental variables is different in the U.S. for January versus nonJanuary months. This issue will be addressed by introducing a dummy variable for January and non-January months into equation (1). 
III. Univariate Analysis of Returns and Fundamental Variables

In Table I, we present average monthly returns for various groups of stocks formed by the four fundamental variables (see also Figure 1). In each panel the stocks are grouped by a different fundamental variable; the grouping procedure is repeated every year based on end of June values. For each of the fundamental variables, four portfolios of equal size are formed for positive values and a special group for negative values. In addition, for each grouping, we present the average values of the other fundamental variables. The last two rows in a panel present the OLS beta calculated using an equally weighted market portfolio based on all the first and second section stocks, and the average number of securities in each portfolio.

From Table I, high E/P stocks outperform low E/P stocks with a difference of 0.40 percent per month between the top and the bottom quartiles. Small stocks achieve substantially higher returns than large stocks, registering a difference of 0.97 percent per month between the two extreme groups. Firms with large, positive book to market ratios earn a premium of 1.10 percent over firms with low, positive book to market ratios. Lastly, the difference in returns between the two extreme groups for the cash flow yield variable is 0.79 percent, which is larger than the spread in returns on the basis of earnings yield. These results are consistent with U.S. findings (e.g., Jaffe, Keim and Westerfield (1989)) and with practitioners' views about the relationship between stock returns and each of the four fundamental variables.

A relatively high return is achieved by stocks with negative fundamental values -- stocks that most likely performed poorly in the period preceding the portfolio formation period. Stocks with negative E/P, $\mathrm{B} / \mathrm{M}$ and $\mathrm{C} / \mathrm{P}$ experience an average monthly return that exceeds 2.5 percent, relative to approximately 1.8 percent for the other groups. The difference in abnormal returns between "losers" and "non-losers" is smaller because of the higher betas of the "losers", although the somewhat higher betas for losers cannot explain the difference in returns. A similar result was obtained by Jaffe, Keim and Westerfield (1989), who concluded that, "Surprisingly, stock with negative earnings outperform many of the positive earnings portfolios in the other five columns."

The results in Table I also reveal that the various fundamental variables are correlated. For example, stocks with high book to market ratios tend to have relatively high cash flow yield ratios. Hence, a 
multivariate analysis is required to disentangle the impact of the various fundamental variables on stock returns.

\section{Regression Results}

\section{A. Seemingly Unrelated Regressions (SUR) with Unadjusted Fundamental Variables}

The results in Table II are based on a SUR model. All the regressions use the same 64 portfolios where first we group by earnings yield, then by size and last by book to market ratio. The first four models include one of the four independent variables at a time. Models 5 to 7 include various combinations of the fundamental variables and model 8 includes all our fundamental variables. The sample comprises stocks from both sections and the fundamental variables, as in previous studies utilizing this approach, are not adjusted for the change in levels over time.

The results are striking. They differ from the findings obtained from U.S. data and from previous

results on the Japanese market. ${ }^{6}$ Moreover, the results conflict with the univariate tests presented in Table I. The earnings yield effect is not significant across the different models; it is not even significant if $E / P$ is the only independent variable. If all the fundamental variables are included, the coefficient on $\mathrm{E} / \mathrm{P}$ has a negative sign, implying that stocks with low earnings yields outperform stocks with high earnings yields.

Size, in general, is significant but, with an unexpected sign in all the models -- large companies in Japan tend to outperform small companies. This finding is very surprising and is also inconsistent with the univariate results in Table I. Recall from Table I that a portfolio of low capitalization stocks outperforms a portfolio of high capitalization stocks by as much as one percent per year. This discrepancy in results may be due to the fact that the distribution of the fundamental variables changes over time, and the pooling procedure fails to account for such changes.

While the $C / P$ and $B / M$ variables are widely used by the financial community as important indicators of value, they have received relatively less attention in the academic literature. We find that the cash flow yield variable and the book to market variable have the expected positive signs. The coefficient on the $C / P$ variable is marginally significant, whereas that on the $B / M$ variable is at least two standard deviations away from zero in all the models. 
All previous studies on the Japanese market examine only stocks from the first section. Hence, to explore whether the inclusion of second section stocks is driving the unexpected results in Table II, we present Table III, which exciudes second section stocks. The results are, in general, similar. According to model 8, which includes all the four variables, E/P and size are statistically significant, but with an unexpected sign. On the other hand, the results for $\mathrm{B} / \mathrm{M}$ and $\mathrm{C} / \mathrm{P}$ parallel previous findings. The results for some of the other models are somewhat sensitive to the sample composition. For example, in model 5 , size is only marginally significant if only first section stocks are included, whereas size is highly significant if data from the first and second sections are pooled.

\section{B. SUR with Adjusted Fundamental Variables.}

The dramatic surge in Japanese stock prices has caused substantial changes in the levels of fundamental variables. Therefore, the traditional approach of applying the SUR model without adjusting for time series variation in the level of fundamental variables is questionable and may account for the unexpected results in Tables II and III. 'Table IV presents the mean, median, 25th percentile and 75th percentile of the four fundamental variables, for every third year. The results reveal a sharp decrease over time in E/P, C/P and $\mathrm{B} / \mathrm{M}$ and a sharp increase in size. For example, in 1973 the mean size is 28.39 billion yen and by 1988 , 300.95 billion yen; the top quartile's boundary is 24.00 billion yen in 1973, which is below the median by 1985 and in the bottom quartile by 1988 . With respect to E/P, the 25 th percentile in 1973 is 3.96 percent, which is in the top quartile by 1988 . Similar changes over time occur with $\mathrm{C} / \mathrm{P}$ and $\mathrm{B} / \mathrm{M}$.

To correct for the model misspecification in Tables II and III, each fundamental variable is deflated each month by its cross-sectional mean value as of the preceding June. The adjusted value preserves the cross-sectional ranking of each fundamental variable at successive points in time. The results with the adjusted fundamental variables for all stocks in the first and second sections are presented in Table V. These results are in sharp contrast to the results in Tables II and III; the findings are now compatible with the univariate tests presented in Table I, and with previous evidence as well. Specifically, E/P, B/M, and $\mathrm{C} / \mathrm{P}$ each individually has a reliably positive influence on subsequent realized returns, while a reliably negative relationship exists between size and future returns. Model 5 attempts to unravel the separate influences of size and earnings yield on returns. While the t-statistics suggest that the coefficients are not 
estimated with a high degree of precision, neither variable dominates the other. Adding the book to market ratio as the third independent variable in Model 6, however, robs both size and earnings yield of any predictive power. It would thus appear that both the size and earnings yield effects are subsumed in our sample by the influence of the book to market ratio. Such a model has not been previously tested in the literature, and these results indicate the sensitivity of inferences to model specification.

In Model 7, earnings yield is replaced by the cash flow measure. For Japanese firms, the cash flow variable may be more informative than earnings yields, since reported earnings are likely to be distorted by the substantial divergence between economic and reported depreciation. In both Models 7 and 8, where cash flow and earnings yield are simultaneously included, the cash flow variable has a positive coefficient and a tstatistic slightly above two. These results suggest that $\mathrm{C} / \mathrm{P}$ may be more important in predicting returns than $E / P$.

Another variable that bas been overlooked by academics, but which has a wide following among practitioners, is the book to market ratio. This variable consistently has the largest coefficien? and the highest $t$-statistic in every model in Table V. Since the book to market ratio is likely to be less noisy than earnings and cash flow yields, which are very sensitive to the events of a single year, its influence can be detected more reliably. In the full model (Model 8), only the coefficients on $B / M$ and $C / P$ are statistically different from zero. If anything, the results for these two variables may be understated; in forming portfolios, we group by $\mathrm{B} / \mathrm{M}$ last and do not group by $\mathrm{C} / \mathrm{P}$, thereby dampening the dispersion across portfolios in the values of these variables.

The magnitude of the coefficients suggests that the variables are not only statistically significant but economically significant as well. For example, in 1988, for the book to market variable, the difference between the boundaries of the upper and lower 10 percentiles is 1.28 (after dividing by the mean). According to model 8 (Table V), the coefficient of the book to market ratio is 0.0034 , which implies a difference in returns of .44 percent per month.

To examine whether the results are sensitive to the composition of the sample, we present Table VI which includes only stocks from the first section. The results are, in general, similar to those in Table V. In the context of a comprehensive model (Model 8) the coefficients for E/P and size are statistically 
indistinguishable from zero; the effect of $\mathrm{B} / \mathrm{M}$ is highly significant, while the coefficient for cash yield is about 1.8 times its standard error.

The unprecedented appreciation of the Japanese market in recent years has motivated arguments on the applicability of traditional fundamental variables in explaining cross-sectional differences in stock returns. This issue is addressed in Table VM, where we provide results based on adjusted fundamental variables for the second half of the period, 1980 to 1988 . These results should be interpreted with caution because of the relatively short time period. The results from Table $V$ in general carry over, with the only exception being that the effect of the cash flow yield variable becomes statistically weaker in Models 7 and 8 . As before, book to market is highly significant across the different models.

A number of previous papers, in studying the impact of fundamental variables on stock returns, investigate January and non-January months separately. Cook and Rozeff (1984) find a significant E/P and size effect in both January and non-January months; Jaffe, Keim and Westerfield (1989) find that size is significant only in January while $\mathrm{E} / \mathrm{P}$ is significant in both January and the rest of the year.

To address this issue for the Japanese market, we expand the SUR model described in Equation 1, by introducing dummy variables for January and non-January months. Our basic model is:

(2) $R_{p t}-R_{t t}=\alpha_{0 j} D_{j t}+\alpha_{o r}\left(1-D_{j t}\right)+B_{p 1 j}\left(R W_{t}-R_{t t}\right) D_{j t}+\beta_{p 1 r}\left(R W_{t}-R_{t t}\right)\left(1-D_{j t}\right)$

$+B_{p_{2 j}}\left(R E_{t}-R_{t}\right) D_{j t}+B_{p 2 r}\left(R E_{t}-R_{t}\right)\left(1-D_{j t}\right)+\alpha_{i j}(E / P)_{p_{t}} D_{j t}$

$+\alpha_{1 r}(E / P)_{p_{t}}\left(1-D_{j t}\right)+\alpha_{2 j}(L S)_{p_{t}} D_{j t}+\alpha_{2 r}(L S)_{p_{t}}\left(1-D_{j t}\right)+\alpha_{3 j}(B / M)_{p_{t}} D_{j t}$

$+\alpha_{3 r}(B / M)_{p_{t}}\left(1-D_{j t}\right)+\alpha_{4 j}(C / P)_{p_{t}} D_{j t}+\alpha_{4 r}(C / P)_{p_{t}}\left(1-D_{j t}\right)+e_{p t}$

$P=1, \ldots 64 \quad t=1, \ldots 210$

where $D_{j t}$ is a dummy variable that takes the value of one in the month of January and zero otherwise. The other variables are defined as in Equation 1.

In Table VIII results are presented for the comprehensive model (Equation 2) as well as models based on partial sets of fundamental variables. We report results for adjusted fundamental variables. Consistently across all the models, $\mathrm{E} / \mathrm{P}$ has a negative sign in January and is in general significant. This is in contrast to findings in the U.S. where Jaffe, Keim and Westerfield (1989) obtain a much higher positive coefficient for $\mathrm{E} / \mathrm{P}$ in January than in other months of the year ( 0.0633 vs 0.0209 , their Tagble II). The results for $\mathrm{E} / \mathrm{P}$ for non-January months are similar to the results across all the months presented in Table $\mathrm{V}$. 
The results for the size variable also differ from U.S. findings. Jaffe, Keim, and Westerfield (1989) found that the size coefficient is significant only in January. In Japan, the size coefficient is in general not significant and there is no noticeable difference between January and non-January months. ${ }^{8}$ With respect to the remaining two variables, $\mathrm{B} / \mathrm{M}$ and $\mathrm{C} / \mathrm{P}$, January does not seem to be a unique month.

The analysis that compares January to non-January months should be interpreted with care, since there are only 17 Januaries in the sample period. Studies in the U.S., such as Jaffe, Keim and Westerfield utilized much longer time periods. Based on our resuits, and in contrast to the U.S. studies, January does not stand out as a special time period.

\section{Sensitivity Analysis}

In this section the sensitivity of the results presented above will be examined with respect to: (1) various model specifications, (2) grouping procedures, and (3) sample composition. The results presented are based on the SUR and Fama-MacBeth methodologies.

\section{A. Sensitivity Analysis for the SUR Model}

In order to reduce the burden on the reader, Table IX presents results for only three of the models estimated: Models 5,6, and 8 . The first panel of the table investigates the sensitivity of the results to the ranking procedure used to form portfolios. In particular, stocks are aggregated into portfolios first on the basis of the book to market ratio, then by cash flow yield and finally by size. Panel A of Table IX yields results that are qualitatively similar to the findings of the previous section. $B / M$ and $C / P$ continue to exert a reliably positive effect on returns in the subsequent period. While size and returns are still negatively related, the t-statistics for the size variable are sensitive to the specification of the model. The earnings yield variable has a negative coefficient that, in contrast to the earlier results, is now highly significant. Portfolios were also formed using alternative orderings of the variables by which securities are ranked; the basic findings of the previous section are essentially unaltered.

Panel B investigates whether the results are sensitive to the generalized least squares correction

employed in the SUR procedure to correct for the contemporaneous correlation of the residuals. In the first pass of the SUR procedure, the time series and cross-sectional observations are pooled, and the model is 
estimated under ordinary least squares, without adjusting for the residual correlations; it is these estimates from the first pass that are reported in Panel B of Table IX. While the evidence there reveals that the general results are robust, there are substantial changes in the magnitudes of individual coefficients and their associated t-values. For example, under Model 8, the coefficient of $\mathrm{B} / \mathrm{M}$ and its t-statistic are 0.0057 and 6.02, respectively, in Panel B of Table IX; the corresponding values from Table V are 0.0034 and 3.03. These differences are consistent with non-negligible correlations across portfolio residuals, illustrating the potential advantage of employing the SUR methodology.

The results in Panel C of Table IX exclude nonsurviving firms from the sample (a total of 123 companies between 1971 and 1988). Most studies of foreign stock markets suffer from such survivorship bias - information on delisted firms is generally not available from the commercial services that typically furnish the data for such studies. To the best of our knowledge, all prior studies of the Japanese market lack information on delisted companies. In accordance with the results of Banz and Breen (1986) using U.S. data, we also find that the survivorship bias appears to affect the outcome of the statistical tests. Model 5, which includes both size and earnings yield, is a specification that has appeared in many studies. Applying this model to surviving firms only leads to the conclusion that both $\mathrm{E} / \mathrm{P}$ and size have the expected signs and are highly significant. When delisted firms are included (as in Table V), however, E/P and size retain their expected signs, but their t-statistics fall below two. In the sample containing only surviving firms, the influence of size tends to be statistically stronger -- its t-statistic in Model 8 is -1.94 , relative to -1.15 when delisted firms are included.

\section{B. Fama and MacBeth Procedure}

As a final check on the robustness of the results, this section presents alternative estimates of Models 5, 6, and 8 using the methodology developed in Fama and MacBeth (1973).

In Table X, the first four panels are based on portfolios formed from securities ranked first by earnings yield, then by size and finally by book to market ratio. The results in the last panel are for individual securities. In June of each year, the beta coefficients for each security (with respect to both the equaily and value weighted market indices) are estimated from the most recent thirty-six months of data. The risk measures of the individual securities in a portfolio are averaged to obtain the portfolio risk 
estimates. Cross-sectional regressions relating returns to betas and fundamental variables from the prior period are then conducted in each of the next twelve months.

As suggested by Litzenberger and Ramaswamy (1979), two possible ways of averaging the time series of coefficients from the monthly cross-sectional regressions are presented: a simple average (Panel A of Table $\mathrm{X}$ ) and a weighted average, where the weights are inversely proportional to the variance of each monthly estimate (Panel B). In line with the results from the SUR model, portfolio returns are reliably and positively related to $\mathrm{B} / \mathrm{M}$ and $\mathrm{C} / \mathrm{P}$. While the market capitalization variable has a negative coefficient, its $t$ statistic is somewhat sensitive to the specification of the model. The sign of the coefficient for earnings yield, however, is contrary to intuition. Evidently, at least two of the fundamental variables -- the book to market ratio and cash flow yield -- have predictive power for portfolio returns, even after allowing the relationship between returns and fundamentals to vary each month.

The results obtained earlier from the SUR model suggest that residual correlations across portfolios may be substantively important (Table IX, Panel B). In Panel C of Table X, the results for each monthly cross-sectional regression are obtained using generalized least squares. The estimated residual covariance matrix used to form the cross-sectional estimates is the same matrix obtained from the SUR model. The results in Panel $C$ are similar to those in the previous panel; the main effect of the generalized least squares adjustment is to lower the t-statistics for the size variable.

The Fama and MacBeth approach assumes that the coefficients estimated every period are drawn from a stationary distribution. Changes over time in the levels of the explanatory variables will invalidate this assumption. To alleviate this problem, we follow the same approach as for the SUR procedure and divide the fundamental variables each month by the corresponding cross-sectional average from the previous June. Panel D of Table X reports the simple time-series average of the monthly coefficients estimated using ordinary least squares. No substantive changes arise as a result of adjusting the fundamental variables for changes in levels over time; the results in Panel D essentially mimic those of Panel A.

In panel $E$ we present results at the level of individual securities. In a recent paper $L$ and MacKinlay (1989) point out biases in statistical inferences when portfolios are formed by some empiricallymotivated fundamental attributes. They suggest that the bias is less severe when data on individual securities is used. Another advantage of conducting the analysis at the level of individual securities is that arbitrary 
decisions on the order of grouping securities into portfolios do not have to be made. As a result, the explanatory variables are all assigned equal importance beforehand. In comparing the relative importance of size and earnings yield (Model 5), each variable has the expected sign. On the basis of their t-statistics, each variable contributes some predictive power for returns that is not accounted for by the other. When additional explanatory variables are introduced, however, as in Models 6 and 8, the coefficient for the E/P switches sign and becomes negative. On the other hand, the coefficient for size is only slightly less than two standard errors below zero. In both Models 6 and 8, the coefficients for $B / M$ and $C / P$ are positive, and highly significant. Overall, the results with individual securities in Panel E suggest that our findings cannot be entirely attributed to biased test procedures, nor to the methods used to group securities into portfolios.

\section{A Trading Strategy Based on Book to Market Ratio and Cash Flow Yield}

After considering all the various specifications examined, the two fundamental variables with the most significant association with stock returns are the book to market ratio and cash flow yield. There is of course the possibility that some other variables, omitted from our list of fundamental variables, are driving stock returns and $\mathrm{B} / \mathrm{M}$ and $\mathrm{C} / \mathrm{P}$ are correlated with these omitted variables. However, even in such a case, profitable trading strategies based on $\mathrm{B} / \mathrm{M}$ and $\mathrm{C} / \mathrm{P}$ can be designed if the correlation between these variables and the omitted variables can be assumed constant.

In Table XI average monthly returns, standard deviations of returns, and betas are presented for portfolios formed each June on the basis of $B / M$ and $C / P$. First, stocks with positive $B / M$ are sorted into four groups; then, within each $\mathrm{B} / \mathrm{M}$ group, stocks with positive $\mathrm{C} / \mathrm{P}$ are also sorted into four groups. This procedure results in a time series of monthly observations on a total of 16 portfolios. The results are graphed in Figure 2.

Within each of the four cash flow yield groups there is a positive monotonic relationship between returns and book to market ratio. The relationship between returns and cash flow yield is nearly monotonic for each of the four book to market groups as well. Comparing a portfolio of stocks with the highest $\mathrm{B} / \mathrm{M}$ and $\mathrm{C} / \mathrm{P}$ ratios to a portfolio of stocks with the lowest $\mathrm{B} / \mathrm{M}$ and $\mathrm{C} / \mathrm{P}$ ratios gives rise to a substantial difference in returns: 2.73 percent versus 1.15 percent respectively. The difference of 1.58 percent per month is almost the size of the average monthy return on an equally weighted portfolio, which during this period of 
time was 1.85 percent. This difference cannot easily be explained by the differences in risk measures such as betas and standard deviations. For example, the highest-performing portfolio has a beta of 0.97 versus a beta of 0.89 for the lowest-performing portfolio. In general, there are substantial differences in returns across the 16 portfolios presented in Table XI, but much smaller differences in betas and standard deviations. These results suggest that fundamental variables may be useful in designing potentially profitable trading strategies.

\section{Summary and Conclusions}

The relationship between fundamental variables and stock returns has attracted a considerable amount of research attention in the U.S. In contrast, there is very limited evidence for the Japanese market. What available evidence there is suffers from methodological problems and a limited data base. In order to fill this void, this paper relates cross-sectional differences in returns on Japanese stocks to the underlying behavior of four fundamental variables: earnings yield, size, book to market ratio and cash yield. Because it is difficult to pre-specify theoretically the correct relationship between observable fundamental variables and stock returns, it is important to verify that any relationships that are uncovered are not merely statistical artifacts. Accordingly, this paper takes great care to apply alternative statistical specifications, and various estimation methods, to a comprehensive, high-quality data set that extends from 1971 to 1988 . In contrast to previous studies, our sample includes both manufacturing and non-manufacturing firms, companies from both sections of the Tokyo Stock Exchange and also delisted securities, hence overcoming the survivorship bias. The resuits are based on returns on individual securities, as well as returns on portfolios, where portfolios are constructed under several different grouping schemes. Our analysis varies the sample period and allows the relationship to differ in January from the rest of the year.

Our findings reveal a significant relationship between fundamental variables and expected returns in the Japanese market. The performance of the book to market ratio is especially noteworthy, this variable is statistically and economically the most important of the four variables investigated. For example, if all the four fundamentals are considered together (Table V, Model 8), the expected difference in returns between the 10 th and the 90 th percentiles of firms ranked by the book to market ratio is 0.44 percent per month. The

importance of this variable persists if the tests are applied to stocks from the first section only, and if only the latter half of the sample period is considered. In addition, the predictive role of the book to market ratio is 
not a phenomenon specific to the month of January. Another variable, cash flow yield, also has a positive and in general highly significant impact on expected returns.

The remaining two fundamental variables -- earnings yield and size -- have been the sole focus of the few available cross-sectional studies on the Japanese market, and have been extensively analyzed in studies on the U.S. market. Our findings confirm the existence of a "size effect"; small firms in our sample tend to outperform larger firms, after adjusting for.market risk and the other fundamental variables.

However, the statistical significance of the market capitalization variable is sensitive to the specification of the model; indeed, in some cases it is not significant.

Of the four variables considered, it is hardest to disentangle the effect of the earnings yield variable. In Table I, for example, a strategy of holding stocks with high $\mathrm{E} / \mathrm{P}$ ratios would be profitable relative to a strategy of holding stocks with low $\mathrm{E} / \mathrm{P}$ ratios. In Table $\mathrm{V}$, if earnings yield is considered in isolation, or if it is included with size, it indeed bas a positive and significant impact on returns. If the book to market ratio is added to the model, however, the coefficient on earnings yield becomes insignificantly different from zero. In the context of the full model, earnings yield even has a negative impact on stock returns, and is in some cases statistically significant.

Overall, of the four variables we considered, the book to market ratio and cash flow yield have the most significant impact on expected returns. This is intriguing, since these two variables, although popular in the financial community, have received very little attention in the academic literature, in comparison to size and earnings yield.

Our findings raise the possibility that earlier studies linking stock returns in Japan or the U.S. to fundamental variables should be interpreted with caution; potentially important explanatory variables may have been omitted. In our context, if we were to restrict attention to the model including only size and earnings yield, in Table $V$, we would be led to conclude, as earlier studies have, that $E / P$ has a positive and nearly significant impact on stock returns. Yet this inference would be reversed when a larger set of fundamental variables is considered. Our results suggest that, in general, such statistical inferences should be made with caution since the correct specification is unknown. 
We do not claim, of course, that the list of fundamental variables employed in this paper is exhaustive. While our sample period is long relative to studies of foreign stock markets, it is nonetheless short and covers fewer different market cycles, in comparison with studies of American data.

Nevertheless, potentially profitable trading strategies based on our fundamental variables can be designed if the correlation between these variables and any omitted variables is constant. In our sample, a portfolio of stocks with the highest values for $\mathrm{B} / \mathrm{M}$ and $\mathrm{C} / \mathrm{P}$ earns 1.58 percent per month more than a portfolio of stocks with the lowest $\mathrm{B} / \mathrm{M}$ and $\mathrm{C} / \mathrm{P}$ ratios.

Many U.S. studies have found January to be a unique month. Following their lead, we allow the relationship between returns and fundamental variables to differ between January and non-January months. In contrast to U.S. studies, however, January does not stand out as a special month. Our sample period, however, extends over only seventeen Januaries.

In addition to using a larger set of fundamental explanatory variables, our results are based on a SUR model that pools time-series observations on portfolios ranked by several fundamental characteristics. Previous applications of this methodology, however, have failed to adjust for changes over time in marketwide levels of the fundamental variables. Since the economic hypothesis predicts that relative returns in a cross-section of portfolios are determined by the relative values of their fundamental variables, the failure to perform this adjustment results in a mis-specified model. In light of the unprecedented rise in Japanese stock prices, this adjustment is substantively important for our study. For example, the results using unadjusted fundamental variables indicate that large companies in Japan significantly outperform small companies. This is at odds with previous evidence and results based on adjusted fundamental variables. Therefore, previous studies that failed to adjust for the level of fundamental variables may have to be reevaluated.

Another commonly used methodology, developed by Fama and MacBeth (1973), is less subject to the above shortcoming because separate cross-sectional regressions are run every month. Indeed, our results with the Fama-MacBeth procedure are compatible with the results from the SUR model using adjusted variables. As an additional safeguard against the biases noted by Lo and MacKinlay (1989), we also apply the Fama-MacBeth procedure to data on individual securities, without grouping into portfolios. There are no essential differences between the results using individual securities and those using portfolio groups. 
Although we make no attempt to rationalize the general level of Japanese equity prices, it is perhaps reassuring nonetheless to find that cross-sectional differences in Japanese stock returns are indeed related to a small set of relatively standard fundamental variables. It is perhaps also understandable that the cash flow yield variable has higher predictive power than does earnings yield, in light of the distortions in the earnings of Japanese firms induced by accelerated depreciation allowances. The noise in reported earnings, related to Japanese accounting standards, may also help to explain why the book to market ratio has such a strong influence. 
1. The requirements include 20 million shares issued, average monthly trading volume of 200,000 shares and continuous dividend payment of more than 5 yen per year over the last three years. See Tokyo Stock Exchange (1988) for details.

2. While TOPIX (Tokyo Stock Price Index) is available from the Tokyo Stock Exchange, this value weighted index is based on section one stocks and excludes dividends.

$$
\text { (1971 through 1988) }
$$

3. Nihon Keizai Shimbun Sha, the equivalent of Moody's Handbooks in the U.S., provides financial information on first and second section stocks listed on the Tokyo Stock Exchange.

4. Cash flow is defined to be the sum of earnings and depreciation; the data were provided by Daiwa Securities.

5. See Brown, Kleidon and Marsh (1983) for a discussion of the SUR methodology.

6. Note that previous studies of the Japanese market typically use a cross-sectional regression approach, rather than the SUR methodology.

7. The variables are deflated by their mean value and hence the size of the coefficients is indicative of their impact on returns.

8. Previous studies of the Japanese market find that small firms outperform large firms in the month of January. These studies, however, rely on a subset of the first section stocks and exclude delisted firms. When our results from Table VIII are replicated for only surviving firms, the coefficient of the size variable is substantially higher in January than in other months. For example, in Model 8 of Table VIII, the coefficient of the size variable is -0.0003 in January and -0.0002 in other months. When delisted firms are excluded, the corresponding estimates are -0.0021 in January and -0.0003 in other months. The discrepancy between our results in Table VIII and those of previous studies can therefore be attributed in part to survivorship bias.

9. Note that since portfolios are not formed by ranking securities on the basis of estimated betas, an extra period for estimating portfolio betas is not necessary. 


\section{References}

Aggarwal, Raj, Takato Hiraki, and Ramesh Rao, 1986, The nature of risk adjusted returns on the Tokyo Stock Exchange: P/E, size and seasonal influences, unpublished paper.

Banz, Rolf, 1981, The relationship between returns and market value of common stocks, Journal of Financial Economics, 9, 3-18.

Banz, Rolf and William Breen, 1986, Sample-dependent results using accounting and market data: some evidence, Journal of Finance, 41, 779-93.

Basu, Sanjoy, 1977, Investment performance of common stocks in relation to their price-earnings ratios: a test of the efficient market hypothesis, Journal of Finance, 32, 663-82.

Basu, Sanjoy, 1983, The relationship between earnings yield, market value and return for NYSE common stocks: further evidence, Journal of Financial Economics, 12, 129-56.

Bernard, Victor and Thomas Stober, 1989, The nature and amount of information in cash flows and accruals, Accounting Review, 64, 624-652.

Bildersee, John, John Chen, and Changwoo Lee, 1990, The international price-earning ratio phenomenon: A partial explanation, Working Paper, New York University.

Brown, Philip, Alan Kleidon, and Terry Marsh, 1983, New evidence on the nature of size-related anomalies in stock prices, Journal of Financial Economics, 12, 33-56.

Brown, Stephen and Toshiyuki Otsuki, 1990, Macroeconomic factors and the Japanese equity markets: The CAPMD project, in Edwin Elton and Martin Gruber(eds.), Japanese Capital Markets, New York: Harper and Row.

Campbell, John and Yasushi Hamao, 1989, Predictable stock returns in the U.S. and Japan: A study of long-term capital market integration, NBER Working Paper No. 3191.

Chen, Nai-fu and Raymond Kan, 1989, Expected returns and the bid-ask spread, Working paper, University of Chicago.

Cook, Thomas and Michael Rozeff, 1984, Size and earnings/price ratio anomalies: One effect or two?, Journal of Financial and Quantitative Analvsis, 19, 449-466.

Darrough, Masako and Trevor Harris, 1989, Do management forecasts of earnings affect stock prices in Japan?, Working Paper, Columbia University.

Elton, Edwin and Martin Gruber, 1988, A multi-index risk model of the Japanese stock market, Japan and the World Economy, 1, 21-44.

Elton, Edwin and Martin Gruber, 1989, Analysts' expectation and Japanese stock prices, Japan and the World Economy, 2.

Fama, Eugene and James MacBeth, 1973, Risk, return and equilibrium: empirical tests, Journal of Political Economy $81,607-636$.

Frankel, Jeffrey, 1989, Japanese finance: A survey, NBER Working Paper no. 3156.

French, Kenneth and James Poterba, 1990, Are Japanese stock prices too high?, Working Paper, University of Chicago. 
Gultekin, Mustafa, Bulent Gultekin and Alessandro Penati, 1989, Capital controls and international capital market segmentation: The evidence from the Japanese and American stock markets, Journal of Finance, 44, 849-869.

Hamao, Yasushi, 1988, An empirical investigation of the Arbitrage Pricing Theory, Japan and the World Economy 1, 45-61. $15,20-26$.

Hamao, Yasushi, 1989, Japanese stocks, bonds, bills and inflation, Journal of Portfolio Management,

Hamao, Yasushi, in collaboration with Roger Ibbotson, 1989, Stocks, Bonds, and Inflation - Japan, 1988 Yearbook, Chicago: Tbbotson Associates.

Hamao, Yasushi, Ronald Masulis and Victor Ng, 1990, Correlations in price changes and volatility across international stock markets, Review of Financial Studies, forthcoming.

Hawawini, Gabriel, 1988, Stock market anomalies and the pricing of equity on the Tokyo Stock Exchange, Working Paper, The Wharton School, University of Pennsylvania.

Huberman, Gur and Shmuel Kandel, 1985, A size based stock returns model, Working paper, University of Chicago.

Ishisuka, Hiroshi, 1987, Jissho Kaikei Joho to Kabuta (Accounting information and stock prices), Tokyo: Dobunkan (in Japanese).

Jaffe, Jeffrey, Donald Keim and Randolph Westerfield, 1989, Earnings yields, market values and stock returns, Journal of Finance, 44, 135-148.

Jaffe, Jeffrey and Randolph Westerfield, 1985, Patterns in Japanese common stock returns: Day of the week and turn of the year effects, Journal of Financial and Quantitative Analysis, 20, 261-272.

Kato, Kiyoshi, William Ziemba and Sandra Schwartz, 1990, Day of the week effects in Japanese stocks, in Edwin Elton and Martin Gruber (eds.), Japanese Capital Markets, New York: Harper and Row.

Kato, Kiyoshi and James Schallheim, 1985, Seasonal and size anomalies in the Japanese stock market, Journal of Financial and Quantitative Analysis, 20, 243-260.

Lakonishok, Josef and Alan Shapiro, 1986, Systematic risk, total risk and size as determinants of stock market returns, Journal of Banking and Finance, 10, 155-132.

Lakonishok, Josef and Seymour Smidt, 1988, Are seasonal anomalies real? A ninety-year perspective, Review of Financial Studies, 1, 403-425.

Litzenberger, Robert and Krishna Ramaswamy, 1979, The effect of personal taxes and dividends on capital asset prices: Theory and empirical evidence, Journal of Financial Economics, 7, 163-196.

Lo, Andrew and A. Craig MacKinlay, 1989, Data-snooping biases in tests of financial asset pricing models, NBER Working Paper no. 3001.

Maru, Junko and Yasubiro Yonezawa, 1984, Nihon no Kabushiki Shijo (The Japanese Stock Market), Tokyo: Toyo Keizai Shimpo Sha (in Japanese).

Nakamura, Takeo and Noboru Terada, 1984, The size effect and seasonality in the Japanese stock market, working paper.

Nihon Keizai Shimbun Sha, 1971 through 1988, Kaisha Joho (Company Handbook), in Japanese. 
Reinganum, Marc, 1981, Mis-specification of capital asset pricing: empirical anomalies based on earnings yields and market values, Journal of Financial Economics, 9, 19-46.

Ritter Jay and Navin Chopra, 1989, Portfolio rebalancing and the turn-of-the-year effect, Journal of Finance, 44, 149-166.

Rosenberg, Barr, Kenneth Reid, and Ronald Lanstein, 1984, Persuasive evidence of market inefficiency, Journal of Portfolio Management, 11, 9-17.

Sakakibara, Shigeki, Hidetoshi Yamaji, Hisakatsu Sakurai, Kengo Shiroshita and Shimon Fukuda, 1988, The Japanese Stock Market, New York: Praeger.

Tokyo Stock Exchange, 1988, Fact Book.

Wilson, Pete, 1986, The relative information content of accruals and cash flows: Combined evidence at the earnings announcement and annual report release date, Supplement to Journal of Accounting

Research, 165-200. 
Table I

Average monthly returns (standard deviations in parentheses), earnings to price (E/P) ratios, size (millions of yen), book to market (B/M) ratios and cash flow to price $(C / P)$ ratios, for portfolios sorted each June by the four fundamental variables over the period 1971-1988 for both first and second section stocks. Also reported is the estimated beta coefficient from an ordinary least squares regression of portfolio returns on an equally weighted market portfolio of all first and second section stocks. $N$ denotes the average number of securities in each portfolio.

(a) Sorted by Earnings to Price ratio

$$
<0 \quad 1 \text { (low) }
$$

2

3

4 (high)

\begin{tabular}{llllll}
\hline Return & .0277 & .0154 & .0174 & .0176 & .0194 \\
& $(0.0665)$ & $(0.0427)$ & $(0.0414)$ & $(0.0413)$ & $(0.0425)$ \\
E/P & -.2461 & .0214 & .0376 & .0530 & .0955 \\
Size & $27,668.5$ & $84,470.4$ & $107,703.0$ & $86,685.0$ & $64,496.4$ \\
B/M & .2032 & .4124 & .4665 & .5463 & .6341 \\
C/P & -.1145 & .0938 & .1062 & .1199 & .1799 \\
Beta & 1.1905 & .9678 & .9529 & .9389 & .9423 \\
N & 105.2 & 275.1 & 279.4 & 279.0 & 276.2
\end{tabular}

(b) Sorted by Size

\begin{tabular}{lllll} 
& 1 (low) & 2 & 3 & 4 (high) \\
\hline Return & .0244 & .0189 & .0161 & .0147 \\
E/P & $(0.0542)$ & $(0.0457)$ & $(0.0421)$ & $(0.0408)$ \\
Size & -.0083 & .0305 & .0361 & .0402 \\
B/M & $4,587.8$ & $13,699.0$ & $36,831.4$ & $262,112.0$ \\
C/P & .5013 & .5086 & .4870 & .4518 \\
Beta & .0977 & .1080 & .0997 & .1076 \\
N & 1.0967 & 1.0297 & .9638 & .8146 \\
& 308.3 & 310.8 & 312.2 & 315.0
\end{tabular}

(c) Sorted by Book to Market ratio

\begin{tabular}{|c|c|c|c|c|c|}
\hline 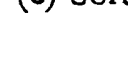 & $<0$ & 1 (low) & 2 & 3 & 4 (high) \\
\hline$\overline{\text { Return }}$ & $\begin{array}{l}.0255 \\
(0.0887)\end{array}$ & $\begin{array}{l}.0133 \\
(0.0431)\end{array}$ & $\begin{array}{l}.0166 \\
(0.0426)\end{array}$ & $\begin{array}{l}.0194 \\
(0.0427)\end{array}$ & $\begin{array}{l}.0243 \\
(0.0464)\end{array}$ \\
\hline$E / P$ & -.5151 & .0211 & .0370 & .0404 & .0441 \\
\hline Size & $10,912.5$ & $126,548.0$ & $79,794.5$ & $65,921.5$ & $49,642.1$ \\
\hline $\mathrm{B} / \mathrm{M}$ & -1.0706 & .2659 & .4292 & .5612 & .8031 \\
\hline$C / P$ & -3439 & .0746 & .1035 & .1240 & .1486 \\
\hline Beta & 1.1322 & .9399 & .9822 & .9812 & .9840 \\
\hline $\mathrm{N}$ & 16.3 & 305.6 & 307.1 & 307.0 & 306.9 \\
\hline (d) Sort & $\begin{array}{l}\text { ed by Cash Yield } \\
<0\end{array}$ & 1 (low) & 2 & 3 & 4 (high) \\
\hline$\overline{\text { Return }}$ & .0262 & .0143 & .0168 & .0190 & .0222 \\
\hline$E / P$ & $\begin{array}{l}(0.0705) \\
-4265\end{array}$ & $\begin{array}{l}(0.0412) \\
0246\end{array}$ & $\begin{array}{l}(0.0408) \\
-0423\end{array}$ & $\frac{(0.0430)}{0510}$ & $(0.0464)$ \\
\hline Size & $17,149.6$ & $121,298.0$ & $75,508.4$ & $62,510.9$ & $72,388.9$ \\
\hline $\mathrm{B} / \mathrm{M}$ & -.0208 & .3783 & .4920 & .5650 & .6170 \\
\hline$C / P$ & -.3303 & .0523 & .0860 & .1242 & .2340 \\
\hline Beta & 1.1942 & .9247 & .9313 & .9820 & 1.0135 \\
\hline $\mathrm{N}$ & 50.1 & 293.5 & 295.8 & 294.4 & 294.0 \\
\hline
\end{tabular}


Table II

Estimated relationship between returns and fundamental variables for both first and second section stocks using a SUR model. The basic model is,

$$
\begin{aligned}
R_{P t}-R_{t t} & =\alpha_{0}+\beta_{p_{1}}\left(R W_{t}-R_{t t}\right)+\beta_{p_{2}}\left(R E_{t}-R_{t t}\right)+\alpha_{1}(E / P)_{P_{t}}+\alpha_{2}(L S)_{p_{t}}+\alpha_{3}(B / M)_{P_{t}} \\
P & =1, \ldots 64 \quad t=1, \ldots 210
\end{aligned}
$$

where, $R_{P_{t}}-R_{t t}$ is the excess return on portfolio $P, R W_{t}-R_{f_{t}}$ and

$R E-R_{\text {ft }}$ are the excess returns on the value weighted and equally weighted indexes, respectively, $E / P$ and $C / P$ are the earnings and cash flow yields, respectively, LS is the natural logarithm of market capitalization and $\mathrm{B} / \mathrm{M}$ is the book to market ratio. Results for various subsets of independent variables are presented as well. The numbers in parentheses are t-values. The order of the grouping is earnings yield, size and book to

\begin{tabular}{|c|c|c|c|c|c|}
\hline Model & Intercept & $E / P$ & LS & $\mathrm{B} / \mathrm{M}$ & $\mathrm{C} / \mathrm{P}$ \\
\hline (1) & $\begin{array}{l}-.0028 \\
(-8.64)\end{array}$ & $\begin{array}{l}-.0001 \\
(-.01)\end{array}$ & & & \\
\hline (2) & $\begin{array}{c}-.0074 \\
(-3.69)\end{array}$ & & $\begin{array}{l}.0005 \\
(2.28)\end{array}$ & & \\
\hline (3) & $\begin{array}{l}-.0043 \\
(-5.79)\end{array}$ & & & $\begin{array}{l}.0028 \\
(2.00)\end{array}$ & \\
\hline (4) & $\begin{array}{l}-.0035 \\
(-7.60)\end{array}$ & & & & $\begin{array}{l}.0058 \\
(1.59)\end{array}$ \\
\hline (5) & $\begin{array}{l}-.0079 \\
(-3.65)\end{array}$ & $\begin{array}{l}.0040 \\
(0.62)\end{array}$ & $\begin{array}{l}.0005 \\
(2.37)\end{array}$ & & \\
\hline (6) & $\begin{array}{c}-.0152 \\
(-5.05)\end{array}$ & $\begin{array}{l}-.0054 \\
(-0.81)\end{array}$ & $\begin{array}{l}.0009 \\
(3.83)\end{array}$ & $\begin{array}{l}.0064 \\
(3.80)\end{array}$ & \\
\hline$(7)$ & $\begin{array}{c}-.0156 \\
(-5.14)\end{array}$ & & $\begin{array}{l}.0010 \\
(3.91)\end{array}$ & $\begin{array}{l}.0055 \\
(2.90)\end{array}$ & $\begin{array}{l}.0025 \\
(0.51)\end{array}$ \\
\hline (8) & $\begin{array}{c}-.0161 \\
(-5.31)\end{array}$ & $\begin{array}{l}-.0202 \\
(-1.85)\end{array}$ & $\begin{array}{l}.0010 \\
(4.13)\end{array}$ & $\begin{array}{l}.0046 \\
(2.25)\end{array}$ & $\begin{array}{l}.0139 \\
(1.74)\end{array}$ \\
\hline
\end{tabular}
market ratio. The sample period is July 1971 to December 1988. 
Table III

Estimated relationship between returns and fundamental variables for first section stocks using a SUR model. The basic model is,

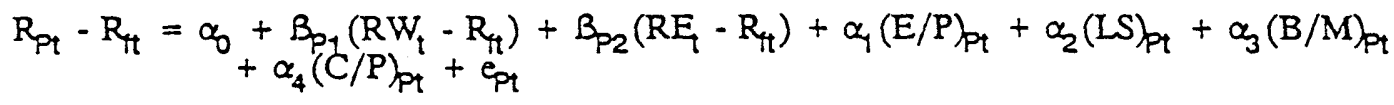

$$
\begin{aligned}
& P=1, \ldots 64 \quad t=1, \ldots 210
\end{aligned}
$$

where, $R_{p_{t}}-R_{t}$ is the excess return on portfolio $P, R W_{t}-R_{t}$ and

$R E-R_{t}$ are the excess returns on the value weighted and equally weighted indexes, respectively, $E / P$ and $\mathrm{C} / \mathrm{P}$ are the earnings and cash flow yields, respectively, $\mathrm{LS}$ is the natural logarithm of market capitalization and $B / M$ is the book to market ratio. Results for various subsets of independent variables are presented as well. The numbers in parentheses are t-values. The order of the grouping is earnings yield, size and book to market ratio. The sample period is July 1971 to December 1988.

\begin{tabular}{|c|c|c|c|c|c|}
\hline Model & Intercept & $E / P$ & LS & $\mathrm{B} / \mathrm{M}$ & $\mathrm{C} / \mathrm{P}$ \\
\hline (1) & $\begin{array}{l}-.0024 \\
(-6.89)\end{array}$ & $\begin{array}{l}-.0015 \\
(-0.27)\end{array}$ & & & \\
\hline (2) & $\begin{array}{l}-.0067 \\
(-2.74)\end{array}$ & & $\begin{array}{l}.0004 \\
(1.76)\end{array}$ & & \\
\hline (3) & $\begin{array}{l}-.0068 \\
(-7.76)\end{array}$ & & & $\begin{array}{l}.0078 \\
(5.39)\end{array}$ & \\
\hline (4) & $\begin{array}{l}-.0049 \\
(-8.56)\end{array}$ & & & & $\begin{array}{l}.0170 \\
(4.49)\end{array}$ \\
\hline (5) & $\begin{array}{l}-.0239 \\
(-6.40)\end{array}$ & $\begin{array}{l}.0001 \\
(0.02)\end{array}$ & $\begin{array}{l}.0004 \\
(1.74)\end{array}$ & & \\
\hline$(6)$ & $\begin{array}{l}-.0208 \\
(-6.16)\end{array}$ & $\begin{array}{l}-.0153 \\
(-2.57)\end{array}$ & $\begin{array}{l}.0013 \\
(4.56)\end{array}$ & $\begin{array}{l}.0119 \\
(7.17)\end{array}$ & \\
\hline$(7)$ & $\begin{array}{c}-.0213 \\
(-6.29)\end{array}$ & & $\begin{array}{l}.0013 \\
(4.62)\end{array}$ & $\begin{array}{l}.0116 \\
(6.30)\end{array}$ & $\begin{array}{l}-.0019 \\
(-0.42)\end{array}$ \\
\hline (8) & $\begin{array}{c}-.0212 \\
(-6.29)\end{array}$ & $\begin{array}{l}-.0353 \\
(-3.61)\end{array}$ & $\begin{array}{l}.0013 \\
(4.71)\end{array}$ & $\begin{array}{l}.0089 \\
(4.48)\end{array}$ & $\begin{array}{l}.0199 \\
(2.68)\end{array}$ \\
\hline
\end{tabular}


Table IV

Distribution of earnings yield, size, book to market ratio and cash flow yield for first and second section stocks for every third year.

(a) Earnings Yield

\begin{tabular}{lllll} 
Year & $\begin{array}{l}\text { First } \\
\text { Quartile }\end{array}$ & Median & Mean & $\begin{array}{c}\text { Third } \\
\text { Quartile }\end{array}$ \\
\hline 1973 & .0396 & .0570 & .0632 & .0780 \\
1976 & .0253 & .0413 & .0481 & .0602 \\
1979 & .0255 & .0412 & .0472 & .0592 \\
1982 & .0316 & .0481 & .0540 & .0686 \\
1985 & .0191 & .0299 & .0361 & .0452 \\
1988 & .0093 & .0158 & .0174 & .0223 \\
\hline
\end{tabular}

(b) Size (Billions of Yen)

\begin{tabular}{lllll} 
Year & $\begin{array}{l}\text { First } \\
\text { Quartile }\end{array}$ & Median & Mean & $\begin{array}{c}\text { Third } \\
\text { Quartile }\end{array}$ \\
\hline 1973 & 2.75 & 8.54 & 28.39 & 24.00 \\
1976 & 3.90 & 11.03 & 34.94 & 32.38 \\
1979 & 6.89 & 16.95 & 45.58 & 43.62 \\
1982 & 7.15 & 18.82 & 65.93 & 54.42 \\
1985 & 14.05 & 36.80 & 131.29 & 100.20 \\
1988 & 35.55 & 78.83 & 300.95 & 210.79 \\
\hline
\end{tabular}

(c) Book to Market Ratio

\begin{tabular}{lllll} 
Year & $\begin{array}{l}\text { First } \\
\text { Quartile }\end{array}$ & Median & Mean & $\begin{array}{c}\text { Third } \\
\text { Quartile }\end{array}$ \\
\hline 1973 & .3920 & .5128 & .5396 & .6640 \\
1976 & .4154 & .5391 & .5706 & .6991 \\
1979 & .3401 & .4517 & .4629 & .5682 \\
1982 & .4506 & .6042 & .6233 & .7767 \\
1985 & .2801 & .3986 & .4379 & .5650 \\
1988 & .1541 & .2306 & .2453 & .3170 \\
\hline
\end{tabular}

(d) Cash Flow Yield

\begin{tabular}{lllll} 
Year & $\begin{array}{l}\text { First } \\
\text { Quartile }\end{array}$ & Median & Mean & $\begin{array}{c}\text { Third } \\
\text { Quartile }\end{array}$ \\
\hline 1973 & .0941 & .1336 & .1549 & .1852 \\
1976 & .0758 & .1114 & .1360 & .1706 \\
1979 & .0631 & .0901 & .1069 & .1296 \\
1982 & .0748 & .1046 & .1269 & $.15 \overline{52}$ \\
1985 & .0427 & .0648 & .0816 & .0971 \\
1988 & .0216 & .0327 & .0409 & .0477 \\
\hline
\end{tabular}




\section{Table V}

Estimated relationship between returns and fundamental variables for both first and second section stocks using a SUR model. The basic model is,

$$
\begin{aligned}
R_{p_{t}}-R_{t t}=\alpha_{0} & +\beta_{p_{1}}\left(R W_{t}-R_{t}\right)+\beta_{p_{2}}\left(R E_{t}-R_{t t}\right)+\alpha_{1}(E / P)_{p t}+\alpha_{2}(L S)_{p_{t}}+\alpha_{3}(B / M)_{p_{t}} \\
& +\alpha_{4}(C / P)_{p t}+e_{p_{t}} \\
P & =1, \ldots 64 \quad t=1, \ldots 210
\end{aligned}
$$

where, $R_{p t}-R_{f t}$ is the excess return on portfolio $P, R W_{t}-R_{t}$ and $R E-R_{Y t}$ are the excess returns on the value weighted and equally weighted indexes, respectively, $E / P$ and $C / P$ are the earnings and cash flow yields, respectively, LS is the natural logarithm of market capitalization and B/M is the book to market ratio. Results for various subsets of independent variables are presented as well. The numbers in parentheses are t-values. The order of the grouping is earnings yield, size and book to market ratio. Each of the fundamental variables is deflated by its cross sectional average from the previous June. The sample period is July 1971 to December 1988.

Model

Intercept

$\mathrm{E} / \mathrm{P}$

LS

$\mathrm{B} / \mathrm{M}$

$\mathrm{C} / \mathrm{P}$

(1)

$$
-.0034
$$

$(-9.75)$

.0007

(1.95)

(2)

$$
-.0011
$$

$(-1.23)$

$-.0005$

$(-1.91)$

(3)

$-.0070$

$(-6.77)$

.0043

(4.05)

(4)

$-.0054$

$(-8.79)$

.0028

$-.0018$

$(-1.80)$

.0007

(1.88)

$-.0005$

$(-1.85)$

(6)

$-.0060$

$(-4.22)$

.0003

(0.91)

$-.0003$

$(-1.30)$

.0042

(4.02)

(7)

$-.0065$

$(-4.49)$

$-.0003$

$(-1.22)$

.0036

(3.31)

$-.0066$

$-.0005$

$(-4.55)$

$(-0.92)$

$-.0003$

$(-1.15)$

.0034

(3.03)

.0014

(4.23)

.0022

(2.07) 
Table VI

Estimated relationship between returns and fundamental variables for first section stocks using a SUR model. The basic model is,

$$
\begin{aligned}
& R_{p t}-R_{f t}=\alpha_{0}+\underset{P}{B_{p 1}\left(R W_{t}-R_{t t}\right)+\beta_{p_{2}}\left(R E_{t}-R_{t t}\right)+\alpha_{1}(E / P)_{p t}+\alpha_{p t}+\alpha_{2}(L S)_{p t}+\alpha_{3}(B / M)_{p t}} \\
& P=1, \ldots 64 \quad t=1, \ldots 210
\end{aligned}
$$

where, $R_{p t}-R_{t}$ is the excess return on portfolio $P, R W_{t}-R_{t t}$ and $R E-R_{t t}$ are the excess returns on the value weighted and equally weighted indexes, respectively, $E / P$ and $C / P$ are the earnings and cash flow yields, respectively, $L S$ is the natural logarithm of market capitalization and $B / M$ is the book to market ratio. Results for various subsets of independent variables are presented as well. The numbers in parentheses are $t$-values. The order of the grouping is earnings yield, size and book to market ratio. Each of the fundamental variables is deflated by its cross-sectional average from the previous June. The sample period is

\begin{tabular}{|c|c|c|c|c|c|}
\hline Model & Intercept & $E / P$ & LS & $\mathrm{B} / \mathrm{M}$ & $\mathrm{C} / \mathrm{P}$ \\
\hline (1) & $\begin{array}{c}-.0034 \\
(-9.61)\end{array}$ & $\begin{array}{l}.0006 \\
(1.79)\end{array}$ & & & \\
\hline (2) & $\begin{array}{l}-.0008 \\
(-0.49)\end{array}$ & & $\begin{array}{l}-.0007 \\
(-1.38)\end{array}$ & & \\
\hline (3) & $\begin{array}{l}-.0066 \\
(-6.45)\end{array}$ & & & $\begin{array}{l}.0037 \\
(3.72)\end{array}$ & \\
\hline (4) & $\begin{array}{l}-.0066 \\
(-8.42)\end{array}$ & & & & $\begin{array}{l}.0024 \\
(3.87)\end{array}$ \\
\hline (5) & $\begin{array}{c}-.0013 \\
(-0.83)\end{array}$ & $\begin{array}{l}.0006 \\
(1.76)\end{array}$ & $\begin{array}{l}-.0007 \\
(-1.38)\end{array}$ & & \\
\hline (6) & $\begin{array}{l}-.0057 \\
(-3.01)\end{array}$ & $\begin{array}{l}.0003 \\
(0.78)\end{array}$ & $\begin{array}{l}-.0004 \\
(-0.73)\end{array}$ & $\begin{array}{l}.0037 \\
(3.70)\end{array}$ & \\
\hline$(7)$ & $\begin{array}{l}-.0061 \\
(-3.22)\end{array}$ & & $\begin{array}{l}-.0004 \\
(-0.66)\end{array}$ & $\begin{array}{l}.0032 \\
(3.06)\end{array}$ & $\begin{array}{l}.0011 \\
(1.75)\end{array}$ \\
\hline (8) & $\begin{array}{c}-.0063 \\
(-3.31)\end{array}$ & $\begin{array}{c}-.0004 \\
(-0.78)\end{array}$ & $\begin{array}{l}-.0003 \\
(-0.55)\end{array}$ & $\begin{array}{l}.0030 \\
(2.82)\end{array}$ & $\begin{array}{l}.0017 \\
(1.76)\end{array}$ \\
\hline
\end{tabular}
July 1971 to December 1988. 
Estimated relationship between returns and fundamental variables for both first and second section stocks using a SUR model for the period 1980-1988. The basic model is,

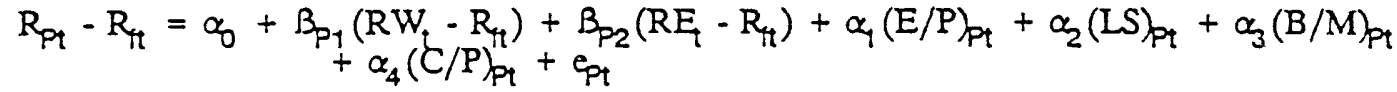

$$
\begin{aligned}
& P=1, \ldots 64 \quad t=1, \ldots 210
\end{aligned}
$$

where, $R_{\rho t}-R_{f t}$ is the excess return on portfolio $P, R W_{t}-R_{t h}$ and $R E_{t}-R_{f t}$ are the excess returns on the value weighted and equally weighted indexes, respectively, E/P and C/P are the earnings and cash flow yields, respectively, $L S$ is the natural logarithm of market capitalization and $B / M$ is the book to market ratio. Results for various subsets of independent variables are presented as well. The numbers in parentheses are t-values. The order of the grouping is earnings yield, size and book to market ratio. Each of the fundamental variables is deflated by its cross-sectional average from the previous June.

\begin{tabular}{|c|c|c|c|c|c|}
\hline Model & Intercept & $E / P$ & LS & $\mathrm{B} / \mathrm{M}$ & $C / P$ \\
\hline (1) & $\begin{array}{l}-.0038 \\
(-11.11)\end{array}$ & $\begin{array}{l}.0014 \\
(3.83)\end{array}$ & & & \\
\hline (2) & $\begin{array}{l}.0002 \\
(0.12)\end{array}$ & & $\begin{array}{l}-.0009 \\
(-1.75)\end{array}$ & & \\
\hline (3) & $\begin{array}{l}-.0072 \\
(-7.20)\end{array}$ & & & $\begin{array}{l}.0047 \\
(4.38)\end{array}$ & \\
\hline (4) & $\begin{array}{l}-.0055 \\
(-10.17)\end{array}$ & & & & $\begin{array}{l}.0031 \\
(5.25)\end{array}$ \\
\hline (5) & $\begin{array}{l}-.0016 \\
(-1.00)\end{array}$ & $\begin{array}{l}.0014 \\
(3.75)\end{array}$ & $\begin{array}{l}-.0007 \\
(-1.38)\end{array}$ & & \\
\hline (6) & $\begin{array}{l}-.0066 \\
(-3.50)\end{array}$ & $\begin{array}{l}.0005 \\
(1.44)\end{array}$ & $\begin{array}{l}-.0003 \\
(-0.54)\end{array}$ & $\begin{array}{l}.0045 \\
(4.18)\end{array}$ & \\
\hline$(7)$ & $\begin{array}{l}-.0070 \\
(-3.67)\end{array}$ & & $\begin{array}{l}-.0002 \\
(-0.43)\end{array}$ & $\begin{array}{l}.0042 \\
(3.86)\end{array}$ & $\begin{array}{l}.0011 \\
(1.79)\end{array}$ \\
\hline (8) & $\begin{array}{c}-.0071 \\
(-3.70)\end{array}$ & $\begin{array}{l}.0001 \\
(0.13)\end{array}$ & $\begin{array}{l}-.0002 \\
(-0.40)\end{array}$ & $\begin{array}{l}.0042 \\
(3.84)\end{array}$ & $\begin{array}{l}.0010 \\
(1.02)\end{array}$ \\
\hline
\end{tabular}


Estimated relationship between returns and fundamental variables for all stocks using a SUR model with dummy variables for January and non-January months. The basic model is described in equation 2 , in the text. Results for subsets of independent variables are presented as well. The models are numbered in accordance with the previous tables. The numbers in parentheses are t-values. The order of the grouping is earnings yield, size and book to market ratio. Each of the fundamental variables is deflated by its cross sectional average from the previous June. The sample period is July 1971 to December 1988.

\begin{tabular}{|c|c|c|c|c|c|c|}
\hline Mod & & Intercept & $E / P$ & LS & $\mathrm{B} / \mathrm{M}$ & $C / P$ \\
\hline$\overline{(1)}$ & $\begin{array}{l}\text { January } \\
\text { February- } \\
\text { December }\end{array}$ & $\begin{array}{l}.0040 \\
(1.96) \\
-.0036 \\
(-10.03)\end{array}$ & $\begin{array}{l}-.0075 \\
(-4.05) \\
.0009 \\
(2.32)\end{array}$ & & & \\
\hline (2) & $\begin{array}{l}\text { January } \\
\text { February- } \\
\text { December }\end{array}$ & $\begin{array}{l}-.0017 \\
(-0.43) \\
-.0015 \\
(-1.49)\end{array}$ & & $\begin{array}{l}-.0003 \\
(-0.25) \\
-.0004 \\
(-1.52)\end{array}$ & & \\
\hline (3) & $\begin{array}{l}\text { January } \\
\text { February- } \\
\text { December }\end{array}$ & $\begin{array}{l}.0048 \\
(0.99) \\
-.0073 \\
(-6.83)\end{array}$ & & & $\begin{array}{l}-.0070 \\
(-1.50) \\
.0045 \\
(4.14)\end{array}$ & \\
\hline (4) & $\begin{array}{l}\text { January } \\
\text { February- } \\
\text { December }\end{array}$ & $\begin{array}{l}.0075 \\
(2.64) \\
-.0059 \\
(-9.32)\end{array}$ & & & & $\begin{array}{l}-.0105 \\
(-3.89) \\
.0033 \\
(4.83)\end{array}$ \\
\hline (5) & $\begin{array}{l}\text { January } \\
\text { February- } \\
\text { December }\end{array}$ & $\begin{array}{l}.0049 \\
(1.20) \\
-.0023 \\
(-2.23)\end{array}$ & $\begin{array}{l}-.0074 \\
(-4.03) \\
.0009 \\
(2.25)\end{array}$ & $\begin{array}{l}-.0003 \\
(-0.26) \\
-.0004 \\
(-1.39)\end{array}$ & & \\
\hline (6) & $\begin{array}{l}\text { January } \\
\text { February- } \\
\text { December }\end{array}$ & $\begin{array}{l}.0076 \\
(1.33) \\
-.0069 \\
(-4.60)\end{array}$ & $\begin{array}{l}-.0074 \\
(-3.87) \\
.0005 \\
(1.32)\end{array}$ & $\begin{array}{l}-.0003 \\
(-0.26) \\
-.0002 \\
(-0.80)\end{array}$ & $\begin{array}{l}-.0024 \\
(-0.50) \\
.0045 \\
(4.15)\end{array}$ & \\
\hline$(7)$ & $\begin{array}{l}\text { January } \\
\text { February- } \\
\text { December }\end{array}$ & $\begin{array}{l}.0088 \\
(1.53) \\
-.0075 \\
(-4.96)\end{array}$ & & $\begin{array}{l}-.0004 \\
(-0.34) \\
-.0002 \\
(-0.70)\end{array}$ & $\begin{array}{l}.0007 \\
(0.14) \\
.0036 \\
(3.28)\end{array}$ & $\begin{array}{l}-.0112 \\
(-3.79) \\
.0019 \\
(2.76)\end{array}$ \\
\hline (8) & $\begin{array}{l}\text { January } \\
\text { February- } \\
\text { December }\end{array}$ & $\begin{array}{l}.0087 \\
(1.51) \\
-.0076 \\
(-5.01)\end{array}$ & $\begin{array}{l}-.0049 \\
(-1.90) \\
-.0006 \\
(-1.07)\end{array}$ & $\begin{array}{l}-.0003 \\
(-0.30) \\
-.0002 \\
(-0.63)\end{array}$ & $\begin{array}{l}-.0001 \\
(-0.02) \\
.0034 \\
(2.96)\end{array}$ & $\begin{array}{l}-.0057 \\
(-1.43) \\
.0028 \\
(2.58)\end{array}$ \\
\hline
\end{tabular}


Table IX

Estimated relationship between returns and fundamental variables for both first and second section stocks using a SUR model. The basic model is,

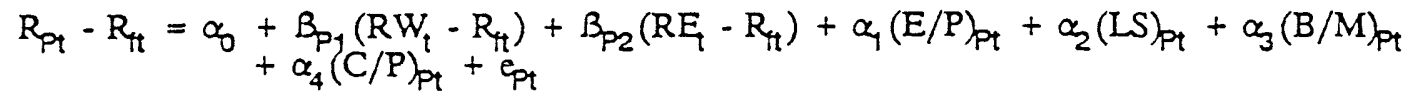

$$
\begin{aligned}
& P=1, \ldots 64 \quad t=1, \ldots 210
\end{aligned}
$$

where, $R_{p t}-R_{t t}$ is the excess return on portfolio $P, R W_{t}-R_{4 / 4}$ and $R E-R_{t t}$ are the excess returns on the value weighted and equally weighted indexes, respectively, E/P and C/P are the earnings and cash flow yields, respectively, $L S$ is the natural logarithm of market capitalization and $B / M$ is the book to market ratio. Results for various subsets of independent variables are presented as well. The numbers in parentheses are $\mathrm{t}$-values. Each of the fundamental variables is deflated by its cross sectional average from the previous June. The sample period is July 1971 to December 1988. In panel A the order of the grouping is book to market, cash yield, and size, whereas in panels $B$ and $C$ it is earnings yield, size and book to market. In panel $B$ the results are for the first pass regression under SUR, without adjustment for the cross correlation of residuals. In panel $\mathrm{C}$ delisted companies are excluded from the sample.

\begin{tabular}{|c|c|c|c|c|c|c|}
\hline Panel & Model & Intercept & $E / P$ & LS & $\mathrm{B} / \mathrm{M}$ & $C / P$ \\
\hline \multirow[t]{3}{*}{$\overline{\mathrm{A}}$} & (5) & $\begin{array}{l}.0006 \\
(0.56)\end{array}$ & $\begin{array}{l}-.0011 \\
(-2.68)\end{array}$ & $\begin{array}{l}-.0006 \\
(-2.31)\end{array}$ & & \\
\hline & (6) & $\begin{array}{l}-.0054 \\
(-3.53)\end{array}$ & $\begin{array}{l}-.0017 \\
(-3.97)\end{array}$ & $\begin{array}{l}-.0005 \\
(-1.83)\end{array}$ & $\begin{array}{l}.0062 \\
(5.19)\end{array}$ & \\
\hline & $(8)$ & $\begin{array}{l}-.0063 \\
(-4.03)\end{array}$ & $\begin{array}{l}-.0030 \\
(-5.46)\end{array}$ & $\begin{array}{l}-.0004 \\
(-1.47)\end{array}$ & $\begin{array}{l}.0054 \\
(4.51)\end{array}$ & $\begin{array}{l}.0026 \\
(3.54)\end{array}$ \\
\hline \multirow[t]{3}{*}{ B } & (5) & $\begin{array}{l}-.0006 \\
(-0.52)\end{array}$ & $\begin{array}{l}.0006 \\
(1.37)\end{array}$ & $\begin{array}{l}-.0007 \\
(-2.37)\end{array}$ & & \\
\hline & (6) & $\begin{array}{l}-.0079 \\
(-5.43)\end{array}$ & $\begin{array}{l}-.0004 \\
(-0.82)\end{array}$ & $\begin{array}{l}-.0003 \\
(-1.13)\end{array}$ & $\begin{array}{l}.0069 \\
(8.84)\end{array}$ & \\
\hline & (8) & $\begin{array}{l}-.0089 \\
(-5.87)\end{array}$ & $\begin{array}{l}-.0015 \\
(-2.25)\end{array}$ & $\begin{array}{l}-.0002 \\
(-0.83)\end{array}$ & $\begin{array}{l}.0057 \\
(6.02)\end{array}$ & $\begin{array}{l}.0031 \\
(2.28)\end{array}$ \\
\hline \multirow[t]{3}{*}{$\mathrm{C}$} & (5) & $\begin{array}{l}-.0012 \\
(-1.00)\end{array}$ & $\begin{array}{l}.0014 \\
(2.74)\end{array}$ & $\begin{array}{l}-.0008 \\
(-2.62)\end{array}$ & & \\
\hline & (6) & $\begin{array}{l}-.0059 \\
(-3.77)\end{array}$ & $\begin{array}{l}.0005 \\
(0.89)\end{array}$ & $\begin{array}{l}-.0006 \\
(-2.09)\end{array}$ & $\begin{array}{l}.0053 \\
(4.48)\end{array}$ & \\
\hline & (8) & $\begin{array}{l}-.0068 \\
(-4.21)\end{array}$ & $\begin{array}{l}-.0007 \\
(-1.01)\end{array}$ & $\begin{array}{l}-.0006 \\
(-1.94)\end{array}$ & $\begin{array}{l}.0044 \\
(3.58)\end{array}$ & $\begin{array}{l}.0028 \\
(2.57)\end{array}$ \\
\hline
\end{tabular}


Table X

Estimated relationship between returns and fundamental variables for both first and second section stocks using the Fama-MacBeth approach. The basic model for month $t$ is,

$\begin{aligned} R_{p t}-R_{t t}=a_{t t} & +b_{1 t} B_{p_{1}}+b_{2 t} B_{p_{2}}+a_{1 t}(E / P)_{p t}+a_{2 t}(L S)_{p t}+a_{3 t}(B / M)_{p t} \\ & +a_{4 t}(C / P)_{p t}+e_{p t}\end{aligned}$

where, $R_{p_{t}}-R_{f_{t}}$ is the excess return on portfolio (security) $P, B_{p_{1}}$ and $B_{p_{2}}$ are betas for a two factor model with the factors being excess returns on value and equally weighted indexes, respectively, $E / P$ and $C / P$ are the earnings yield and cash flow yields, respectively, $L S$ is the natural logarithm of market capitalization and $B / M$ is the book to market ratio. The numbers in parentheses are t-values. The order of the grouping is earnings yield, size and book to market ratio. Results for various subsets of independent variables are presented as well. The sample period is July 1971 to December 1988. The results in panel A are for a simple average of the cross sectional coefficients, in panel B the weight of each monthly coefficient is inversely proportional to the variance of the estimate, in panel $C$ the monthly coefficients are estimated using GLS; in panel $D$ the fundamental variables are divided by cross sectional averages, and in panel $E$ the results are at the level of individual securities.

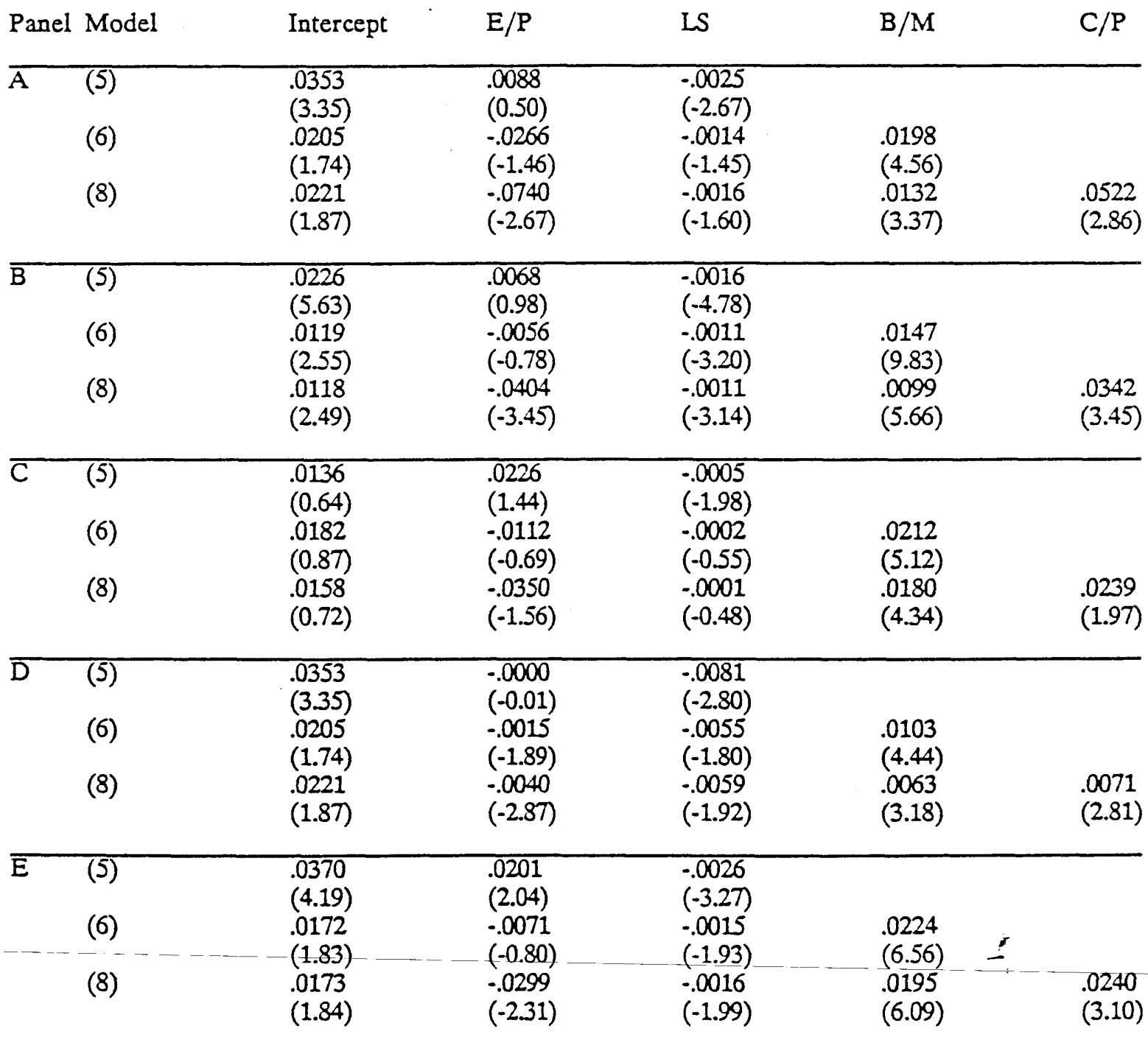


Table XI

Average monthly returns, standard deviations(in parentheses) and betas (in brackets) for portfolios sorted each June first to four groups based on $B / M$ and then to four groups based on $C / P$. The results are for the first and second section stocks and for the period 1971-88. To compute betas an equally weighted index of the first and second sections stocks is used.

\begin{tabular}{cllll} 
& \multicolumn{5}{c}{ Cash Flow Yield } \\
Highest & 3 & 2 & Lowest \\
\cline { 2 - 5 } Highest & .0273 & .0230 & .0238 & .0230 \\
& $(.0501)$ & $(.0491)$ & $(.0471)$ & $(.0476)$ \\
& {$[0.97]$} & {$[1.00]$} & {$[0.96]$} & {$[0.99]$} \\
3 & .0212 & .0194 & .0180 & .0177 \\
Book to & $(.0477)$ & $(.0449)$ & $(.0417)$ & $(.0428)$ \\
Market & {$[1.03]$} & {$[1.00]$} & {$[0.92]$} & {$[0.95]$} \\
2 & .0176 & .0163 & .0152 & .0165 \\
& $(.0477)$ & $(.0434)$ & $(.0423)$ & $(.0438)$ \\
& {$[1.04]$} & {$[0.96]$} & {$[0.92]$} & {$[0.97]$} \\
Lowest & .0156 & .0125 & .0116 & .0115 \\
& $(.0471)$ & $(.0454)$ & $(.0446)$ & $(.0451)$ \\
& {$[0.99]$} & {$[0.94]$} & {$[0.90]$} & {$[0.89]$} \\
\hline
\end{tabular}


Average monthly returns for sorted portfolios

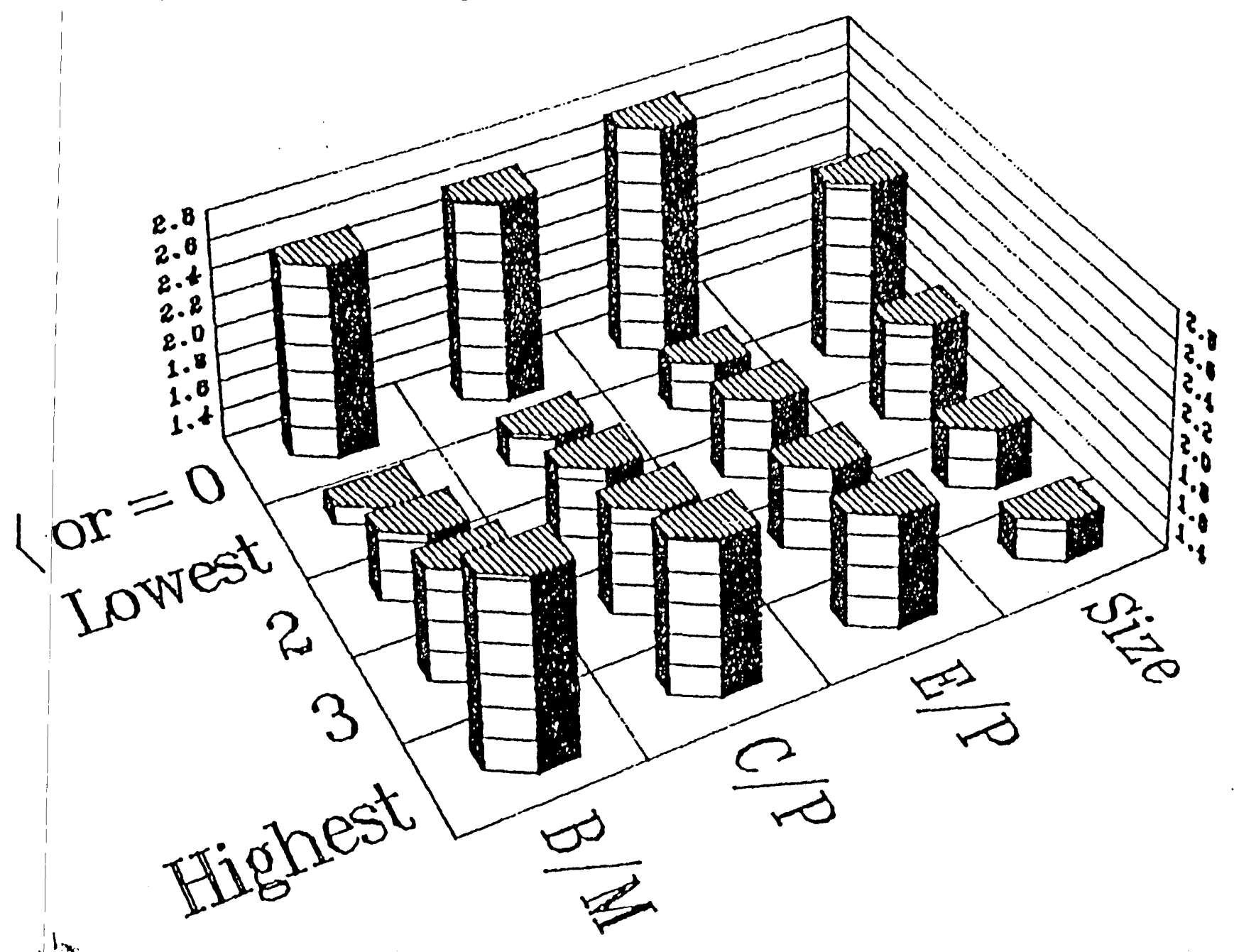

Sorted by size, E/P, B/M and C/P

FIGURE 1 
Average monthly returns for sorted portfolios

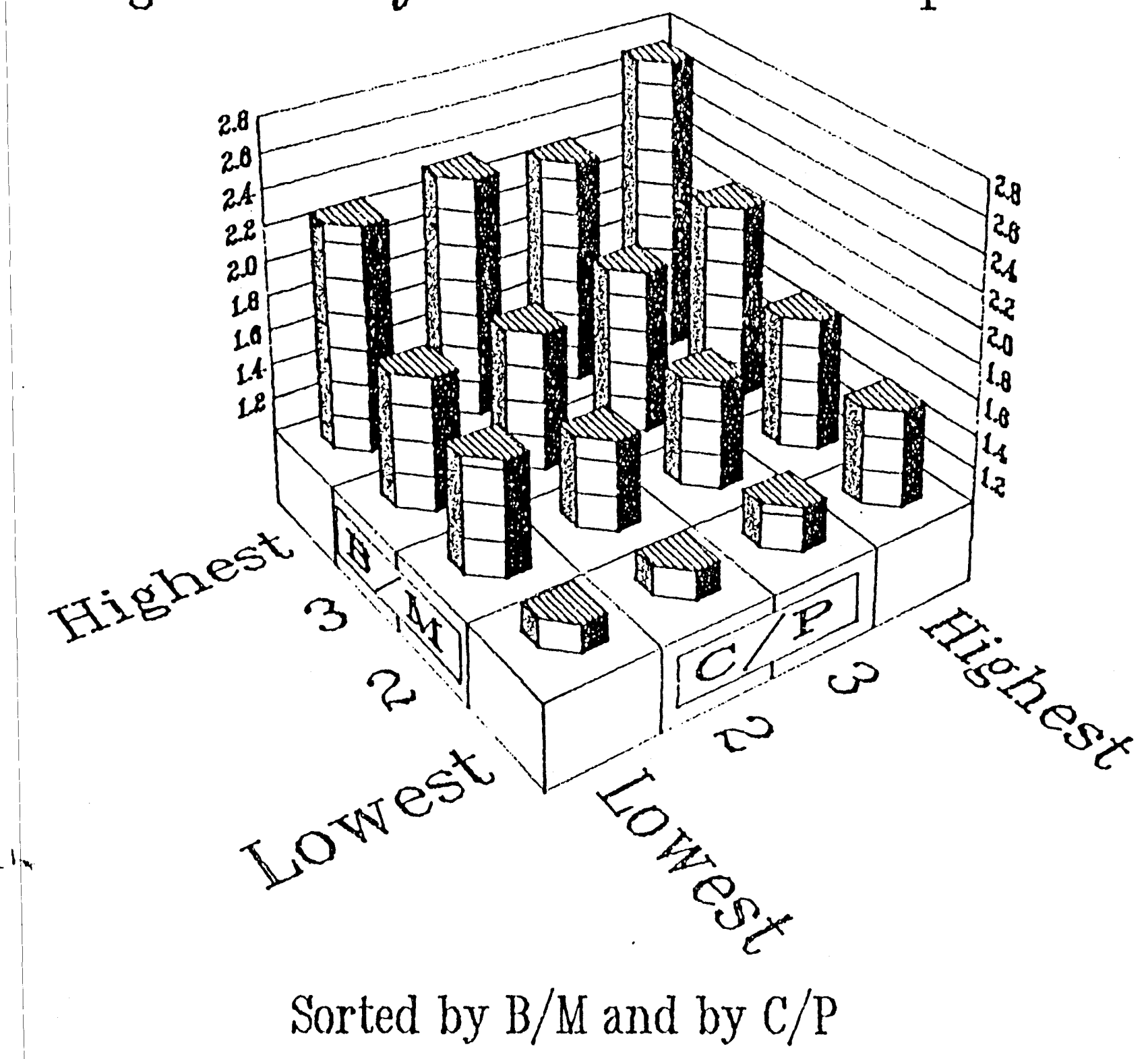

FIGURE 2 